\title{
A STUDY ON OXIDATIVE STRESS AND COMPLETE BLOOD COUNT OF SHEEP BRED IN THE AREA EXPOSED TO DEPLETED URANIUM (DU) AMMUNITION
}

\author{
JOVIĆ $S^{*}$, ALEKSIĆ JELENA*, KRSTIĆ ALEKSANDRA**, STEVANOVIĆ JELKA*, \\ KOVAČEVIĆ-FILIPOVIĆ MILICA*, BOROZAN SUNČICA*, BOŽIĆ TATJANA* \\ and POPOVIĆ DRAGANA* \\ *Faculty of Veterinary Medicine, University of Belgrade, Serbia \\ ** Institute for Medical Research, Belgrade, Serbia. \\ (Received 15th March 2009)
}

The paper presents the results of several health status parameters of sheep bred in the area exposed to depleted uranium (DU) ammunition during NATO bombing of Serbia and Montenegro in 1999. The blood samples of sheep were collected randomly in the region of Bujanovac, in 2004. Complete blood count was performed according to standard laboratory procedures. Concentration of red blood cells malondialdehyde (RBC MDA) and activity of erythrocyte superoxid dismutase (SOD) were determined spectrophotometrically, while the functional activity of leukocytes was investigated by NBT reduction and adhesion test.

The results of complete red blood cells count indicated normocytic hypochromic anaemia. The total number of leukocytes and the differential leukocytes count were within the physiological range. Although the leukocytes adhesiveness was not changed in DU exposed animals, their increased NBT reduction revealed stimulated leukocytes' oxidative burst. This finding, together with significantly increased RBC $M D A$ concentrations, as well as the activity of RBC antioxidant SOD, point to the existence of oxidative stress.

Although the results indicated that animals were under oxidative stress, still there are no conclusive data that it was due to the exposure of $D U$ that entered the environment during military operations.

Key words: sheep, depleted uranium (DU), environment, oxidative stress, peripheral blood, RBC SOD, RBC and MDA

\section{INTRODUCTION}

Uranium is a primordial radioactive element (half-life $10^{9}$ years) and is found in nature as a mixture of three radioisotopes, with different relative abundance: ${ }^{238} \mathrm{U}(99 \%),{ }^{235} \mathrm{U}(0.71 \%)$ and ${ }^{234} \mathrm{U}(0.006 \%)$. It is both chemically toxic and radioactive. As it is water soluble it is easily taken up by plants thus entering food chains and soil/water systems. Humans contain up to $100 \mu \mathrm{g}$ of mainly ingested 
uranium depending on body weight and age (Fisenne and Perry, 1985; Ribera, 1996; Roth et al., 2003). Uranium is regarded as to have no important metabolic function, still its toxic effects are well recognized (Domingo, 2001).

Depleted uranium DU $\left(0.2-0.3 \%\right.$ of $\left.{ }^{235} \mathrm{U}\right)$ is low radioactive waste material, a by-product of uranium processing in nuclear reactors or production of nuclear weapons. Natural and depleted uranium are chemically identical, thus having the same health effects. As a material of high density, penetrability and pyrophoricity, depleted uranium (DU) came into military use in the early 70 ties of the $20^{\text {th }}$ century and was used for the first time in the Gulf War in 1991, and later in the wars in the Balkans in 1990ties (Roth et al., 2003).

Health impacts of DU include an initial exposure of the environment, local population and animals due to DU particles in the air after the explosion and to particles resuspended from contaminated soils and food/feed, and long term possible exposure from contaminated waters, or by dust containing particles with uranium (Ribera, 1996). Toxic effects of DU occur at lower exposure levels than the radiotoxic one, and possible cancer effects in humans may appear after the latency period of one to several decades (Domingo, 2001). Ingested or inhaled, DU appears immediately in the bloodstream, primarily in erythrocytes (Fisenne and Perry, 1985), and although it is rapidly extracted in urine (nearly $90 \%$ in the first 3 months), it subsequently accumulates in kidneys, skeleton, lungs, liver and heart. Health effects of deposited DU are due to alpha particles ionisation effects leading to production of reactive oxygen species (Bogdan et al., 2000). Eventually, when the concentration of free radicals exceeds the level that could be controlled by an effective antioxidant defence, cell membranes, proteins, lipids and nucleic acids are possibly damaged (Lorimore and Wright, 2003), provoking a spectrum of tissue injuries and exhibiting different clinical signs (Graeub, 1994; Nussbaum and Kohnlein, 1994).

During military attacks in Serbia and Montenegro in 1999 about 500000 DU missiles $\left(3600 \mathrm{~kg}\right.$ of uranium oxide of total activity of $18.3 \times 10^{10} \mathrm{~Bq}$ ) were fired. Eleven locations in South Serbia (Bujanovac, Vranje) and Montenegro (Lustica Peninsula) were hit, all under the $44^{\text {th }}$ parallel. The highest contamination measured in soils on the targeted sites was $200000-250000 \mathrm{BqU} / \mathrm{kg}$ soil, and once the sites were isolated and decontaminated, the top layers of soil and the missile fragments were stored as radioactive waste (FM REPORT, 2000; Popovic et al., 2002). The study of the possible health effects on animals, mainly cows and sheep bred in the areas exposed to DU ammunition started in 2003 (Bozic et al., 2003; Aleksic et al., 2004) and are in progress.

The aim of this paper was to analyse the possible effect of DU on blood cells of sheep bred in the exposed areas. The results are discussed concerning data of complete blood count, functional activity of leukocytes (respiratory burst and adherence), oxidative stress markers and the content of DU that entered the environment during bombing. 


\section{MATERIAL AND METHODS}

\section{Animals and blood sampling}

The samples were collected randomly on 6 locations in the region of Bujanovac (Novo Selo, Borovac), in the spring of 2004. Blood samples were taken from 20 clinically healthy sheep (Merinos/Svrljig, age 3-6 years), from the vena jugularis (using acid-citrate dextrose as anticoagulant). Animals were randomly selected from 9 households and were held on pastures with free access to water, near the bombed area. In the control group there were 10 sheep from a location not exposed to DU (a farm nearby Belgrade). The differences among the groups considering age, health status, nutrition, etc. were not significant and thus could not affect the results.

\section{Haematological and biochemical analysis}

Complete blood count was performed according to standard laboratory procedures. Haemoglobin concentration was detected by colorimetric assay, at $540 \mathrm{~nm}$ (spectrophotometer Spekord M40, Karl Zeiss, Jena). Red blood cells malondialdehyde (RBC MDA) concentrations were determined using the colorimetric procedure at $535 \mathrm{~nm}$ (spectrophotometer Spekord M40, Karl Zeiss, Jena). Superoxid dismutase activity (SOD) was evaluated by spectrophotometric procedure at 480-540 nm on Specord M40 (Karl Zeiss, Jena).

\section{Preparation of leukocytes, leukocyte activation and leukocytes adhesion} analysis

Peripheral blood leukocytes were isolated from heparinized blood. The blood was mixed with 6\% HES (Plasmasteril/Frasenius, Hamburg) in 1:7 ratio and centrifuged at $600 \mathrm{~g}$ for $15 \mathrm{~min}$. After that lukocytes-rich pellet fraction was removed. Red blood cells where then lysed with isotonic $\mathrm{NH}_{4} \mathrm{Cl}$ solution (155 mmol/L NH${ }_{4} \mathrm{Cl}, 10 \mathrm{mmol} / \mathrm{L} \mathrm{KHCO}_{3}, 0.1 \mathrm{mmol} / \mathrm{L} \mathrm{EDTA}, \mathrm{pH}$ 7.4). The remaining leukocytes were washed twice and resuspended in Dulbecco's modified Eagle's medium (DMEM, Sigma Chemicals, USA) supplemented with 10\% FCS (Sigma Chemicals, USA).

The activation of leukocytes was evaluated by respiratory burst cytochemical assay (Monboisse et al., 1991), measured by intracellular reduction of nitroblue tetrazolium salt (NBT, MERCK, Germany). Naimly, NBT reduction occurs by a chemical reaction between the dye and the superoxide anion $\left(\mathrm{O}_{2}^{-}\right)$ generated by the activated respiratory burst NADPH oxidase. To determine the spontaneous or induced reduction of NBT, leukocytes were incubated for 30 min in the medium only, or in the presence of $50 \mathrm{ng} / \mathrm{mL}$ PMA (phorbol-12-myristate-13acetate, Sigma Chemicals, USA), respectively. Formazan produced by cells was extracted overnight in $10 \% \mathrm{SDS}-0.1 \mathrm{~N} \mathrm{HCl}$ at $37^{\circ} \mathrm{C}$ and was measured spectrophotometrically at $540 \mathrm{~nm}$ by an ELISA 96-well plate reader (Labsystems Multiskan PLUS, Finland).

Adhesion of leukocytes to plastics was performed by a modified assay initially described by Oez et al. (1990). To measure spontaneous or stimulated 
adhesion, cells were incubated for $60 \mathrm{~min}$ in medium only (spontaneous adhesion) or in the presence of $50 \mathrm{ng} / \mathrm{ml}$ PMA (induced adhesion). After incubation, cells adhering to the plastic surface were fixed with methanol and stained with $0.1 \%$ crystal violet. The plates were washed three times in running water and left to air dry. The dye was dissolved in $200 \mu \mathrm{L}$ of $33 \%$ acetic acid and the absorbance was measured at $540 \mathrm{~nm}$ by ELISA 96-well plate reader.

\section{Statistics}

Statistical analysis was performed in EXCEL, by descriptive statistics tools and unpaired Student's t - test. $P$ value less then 0.05 was considered significant.

\section{RESULTS}

The results of biochemical and haematological measurements are presented in Table 1. The results indicated that all animals in the exposed group had a significantly lower red blood cells count and packed cell volume PCV $(p<0.001)$ compared to the control group. There were no significant differences in haemoglobin concentration, as it was the case in our previous study on sheep and cows (Božić et al., 2003; Stevanović et al., 2005). Mean corpuscular volume $\mathrm{MCV}$ and mean corpuscular haemoglobin concentration MCHC were within the physiological range thus indicating normocytic hypochromic anemia. The exposed group had significantly increased $(p<0.001)$ both RBC MDA concentration and SOD activity compared to the control group.

Table 1. Erythrocytes count $(E r)$, haemoglobin concentration $(\mathrm{Hb})$, packed cell volume (PCV), activity of RBC SOD and RBC MDA concentration in sheep. (MV-means, SE- standard error)

\begin{tabular}{|l|c|c|c|c|}
\hline & \multicolumn{2}{|c|}{ Exposed group } & \multicolumn{2}{c|}{ Control group } \\
\hline \hline Parameter & $\mathrm{MV}$ & $\mathrm{SE}$ & $\mathrm{MV}$ & $\mathrm{SE}$ \\
\hline $\mathrm{Er}\left(\mathrm{x} 10^{12} / \mathrm{L}\right)$ & $6.34^{\star \star *}$ & 0.22 & 10.20 & 0.08 \\
\hline $\mathrm{Hb}(\mathrm{g} / \mathrm{L})$ & 87.1 & 3.23 & 87.60 & 4.19 \\
\hline $\mathrm{PCV}(\%)$ & $31.9^{\star \star *}$ & 0.20 & 36.30 & 1.15 \\
\hline $\mathrm{SOD}(\mathrm{U} / \mathrm{gHb})$ & $5429^{\star \star *}$ & 5960 & 2497 & 115 \\
\hline $\mathrm{RBC} \mathrm{MDA}(\mathrm{nM} / \mathrm{gHb})$ & $14.2^{\star * *}$ & 2.72 & 0.05 & 0.005 \\
\hline
\end{tabular}

Significance: ${ }^{* \star \star} p<0.001$ vs. control

Number of leukocytes and relative contribution of monocytes, lymphocytes and all granulocytes were within the physiological range in the exposed and control group of animals.

The results of spontaneous and PMA-stimulated NBT reduction test and adhesion of peripheral blood leukocytes are presented in Table 2. 
Acta Veterinaria (Beograd), Vol. 59. No. 5-6, 481-488, 2009.

Jović $S$ et al.: A study on oxidative stress and complete blood count

of sheep bred in the area exposed to depleted uranium (DU) ammunition

Table 2. Results of spontaneous and PMA-stimulated NBT reduction test and adhesion of peripheral blood leukocytes (MV - means, SE - standard error)

\begin{tabular}{|c|c|c|c|c|c|c|c|c|}
\hline & \multicolumn{4}{|c|}{ NBT reduction test } & \multicolumn{4}{c|}{ Adhesion } \\
\cline { 2 - 9 } & PMA (0 ng/mL) & PMA (50 ng/mL) & PMA (0 ng/mL) & \multicolumn{2}{c|}{ PMA (50 ng/mL) } \\
\cline { 2 - 9 } & $\begin{array}{c}\text { Control } \\
\text { group }\end{array}$ & $\begin{array}{c}\text { Exposed } \\
\text { group }\end{array}$ & $\begin{array}{c}\text { Control } \\
\text { group }\end{array}$ & $\begin{array}{c}\text { Exposed } \\
\text { group }\end{array}$ & $\begin{array}{c}\text { Control } \\
\text { group }\end{array}$ & $\begin{array}{c}\text { Exposed } \\
\text { group }\end{array}$ & $\begin{array}{c}\text { Control } \\
\text { group }\end{array}$ & $\begin{array}{c}\text { Exposed } \\
\text { group }\end{array}$ \\
\hline \hline MV & 0.071 & $0.155^{\star}$ & 0.108 & $0.292^{\star \star \star}$ & 0.11 & 0.143 & 0.191 & 0.238 \\
\hline SE & 0.01 & 0.015 & 0.019 & 0.035 & 0.023 & 0.016 & 0.05 & 0.03 \\
\hline
\end{tabular}

Significance at ${ }^{* *} p<0.01$ vs. control and ${ }^{*} p<0.05$ vs. control

The exposed group of animals in comparison with control group had significantly higher, both, spontaneous $(p<0.05)$ and induced $(p<0.001)$ leukocytes respiratory burst. In contrast, the adhesion of leukocytes nor spontaneous, neither stimulated did not differ between groups.

\section{DISCUSSION}

Exposures to low level ionising radiation induce free radicals production setting off reactions that could result in tissue damage and failure of the immune system (Graeub, 1994; Bogdan et al., 2000). It is also likely that long-term exposures to low-doses of radiation could be more damaging than the same doses received accidentaly (Graeub, 1994) presuming the fewer reactive oxygen species present in the body fluids, the greater possiblility for cell damage. This is due to the fact that although more oxygen radicals are created by higher doses of radiation, they recombine faster and thus become ineffective before reaching and damaging the membrane (Graeub, 1994).

Reb blood cells are optimal to detect oxidative damages as erythrocytes are direct targets of oxygen radicals. Due to oxidative stress, erythrocyte membrane lipids and proteins may undergo serious oxidative damage. But, sometimes high concentrations of antioxidants and reducing agents (glutathione) in red blood cells make them effective scavengers of $\mathrm{O}_{2}$ radicals, so while passing through the tissue undergoing oxidative stress they may prevent organ damage at the expense of red blood cells oxidation (Christopher, 1996).

In our experiment in 2004, that followed the study in 2003, the sheep from the area exposed to DU ammunition had a significantly higher activity of the antioxidant enzyme SOD than the animals in the control group. As SOD inactivates free radicals, catalysing transformation of the toxic superoxide anion in less toxic $\mathrm{H}_{2} \mathrm{O}_{2}$ (Bogdan et al., 2000), this may indicate that oxidative stress overwhelms antioxidative defence capacity, or could point to free radicals induced damages in genes controlling production of SOD (Roth et al., 2003).

The results of our present investigations also confirmed that the sheep bred in the exposed area exhibited strong normocytic normochromic anemia, as previously was found by Božić et al. (2003); Aleksić et al. (2004), and Stevanović et al. (2005). Morphologically defined anemia indicates that there is no marked 
reticulocytosis, which corresponds to the fact that sheep do not respond with increased retikulocyte count, unless the anemia is profound. Therefore, disturbances of hematopoiesis, induced by different environmental factors, could not be excluded as a possible mechanism in the pathophysiology of detected anemia. The RBC MDA concentration was more than 280 times higher in the exposed group than in the control group. This result is consistent with the data on oxidative stress (Christopher, 1996). This also agrees with other reports on the damages of erythrocytes plasma membrane induced by reactive oxygen species (Lunec, 1996).

Results from this investigation showed significantly increased spontaneous and stimulated NBT reduction in peripheral blood leukocytes from exposed sheep in comparison to controls, which might suggest that mechanisms of oxidative stress were activated in sheep bred in the exposed area. As all examined sheep were clinically healthy, the obtained results indicate that animals were exposed to some kind of oxidative stress, due to possible disturbances in the environment. This is in agreement with the investigations on liver damage and kidney malfunction in animals from the same area concluding that the presence of polyPA in both cows and sheep and protein modifications in sheep indicated a harmful environmental impact, possibly due to radiation (Gadjanski et al., 2003). Our previous study demonstrated that PMA stimulated peripheral blood leukocytes adhesiveness was elevated in cows from DU exposed areas (Stevanović et al., 2005). However, in the present study the spontaneous and PMA stimulated leukocytes' adhesiveness was not changed. The observed difference could not be explained without further studies.

The results on radioactivity measurements in the exposed area indicated that, although the region was exposed to DU ammunition (FM REPORT, 2000; UNEP REPORT, 2001; UNEP REPORT, 2002) it did not reache the soil and food on a larger extent, mainly due to the fact that the contamination was local, around the targeted sites, or the shells did not explode and therefore, possible contamination could be only due to the corrosion effect (UNEP REPORT, 2002). Still, the results of some recent studies on radiocontamination of bioindicator species as lichenss and mosses point to possible contamination of the environment on a larger scale around the targeted sites (Loppi et al., 2003). Altogether, clinically healthy animals, with normocytic hypochromic anemia and clear evidence of oxidative stress, could have subclinical inflammatory condition either due to biological agents, micronutrition deficiency or environmental radioactive contamination.

In conclusion, increased NBT reduction, increased RBC MDA concentrations, as well as the activity of RBC antioxidant SOD, point to the existence of oxidative stress. Although the results indicated that animals were under oxidative stress, still, there are no conclusive data that it was due to exposure of DU that entered the environment during military actions.

ACKNOWLEDGEMENTS:

The study was supported by the Ministry of Science, Technology and Development of the Republic of Serbia (Grant No.1518/2002 and 20061-TR). We wish to thank the veterinarians at Veterinary Station Bujanovac, for their great help in this work. 
Address for correspondence:

Assistent Mr Slavoljub Jović

Department of Physiology

Faculty of Veterinary Medicine

Bul. oslobodjenja 18

11000 Belgrade

Serbia

E-mail: romanov@vet.bg.ac.yu

\section{REFERENCES}

1. Aleksic J, Lukic S, Jovic S, Kovacevic-Filipovic M, Vlaski M, Bozic T, Popovic D, Stevanovic J, 2004 Investigation of Oxidative stress in Sheep Bred in Areas Exposed to Depleted Uranium (DU) Ammunition. Jug Physiol Pharmacol Acta 40, 1/3, 139-44.

2. Bogdan C, Diefenbach A, Rollinghof $M, 2000$, Reactive oxygen and reactive nitrogen intermediates in innate and specific immunity, Curr Opin Immunol 12, 64-76.

3. Bozic T, Stevanovic J, Kovacevic-Filipovic M, Borozan S, Popovic D, Todorovic D, 2003, Possible effects of depleted uranium (DU): I. Changes in cellular and biochemical values in peripheral blood of ruminants in exposed areas, Central Europ J of Occup Environ Med, 9, 4, 267-72.

4. Christopher M, 1996, "The red blood cells and antioxidative damage: innocent bystander or effective scavenger". Proceedings of the VII Congress of the International Society of Animal Clinical Biochemistry, Glasgow, 47-9.

5. Domingo JL, 2001, Reproductive and developement toxicity of natural and depleted uranium: a review, Reproductive Toxicity, 15, 603-9.

6. Fisenne I., Perry P, 1985, Isotopic U concentration in human blood from New York City donors, Health Phys, 49, 6, 1270-5.

7. FM REPORT, 2000, Consequences of NATO Bombing. Federal Ministry of Science and Environment, Belgrade.

8. Gadjanski-Omerović N Gordana, Borozan Z Sunčica, Božić P Tatjana, Popović Lj Dragana, 2003, Possible Effects of Depleted Uranium (DU): II. Damage of Liver and Kidney Malfunction in Animals of Exposed Areas. Centr Eur J Occup Environ Med, 9, 4, 267-72.

9. Graeub R, 1994, Petkau Effect, The Devasting Effect of Nuclear Radiation on Human Health and Enviroment, second ed., Four Walls Eight Windows, NY.

10. Loppi S, Riccobono F, Zhang ZH, Savic S, Ivanov D, Pirintsos S, 2003, Lichen as biomonitors of uranium in the Balkan area, Environm. Pollution, 125, 277-80.

11. Lorimore SA, Wright EG, 2003, Radiation induced genomic instability and bystander effects: Related inflammatory type responses to radiation-induced stress and unjury? A Rev Int $J$ Radio Biology, 79, 1, 15-25.

12. Lunec J, 1996, Oxidative stress and antioxidants. Proceed. Of VII Congress of Inter. Soc. of Animal Clinical Biochemistry, 45-7.

13. Monboisse JC, Garnotel R, Randoux A, Dufer J, Borel JP, 1991, Adhesion of human neutrophils to and activation by type-I collagen involving a 2 integrin. $J$ Leukoc Biol, 50, 373-80.

14. Nussbaum RH, Kohnlein W, 1994, Incosistencies and open questions regarding low-dose health effects of ionizing radiation, Environ Health Perspect, 102, 656-67.

15. Oez S, Welte K, Platzer E, Kalden JR, 1990, A simple assay for quantifiying the inducible adherence od neutrophils, Immunobiology, 180, 308-15.

16. Popovic D, Djuric G, Todorovic D, 2002, Possible Impacts Of Depleted Uranium On Health And Environment: The Case Of Yugoslavia, Central Europ J of Occup Environ Med, 8, 227-31.

17. Ribera $D, 1996$, Uranium in the environment: occurrence, transfer, and biological effects, Rev Environ Contam Toxicol, 146, 53-89.

18. Roth P, Hoellriegl V, Werner E, Schramel $P, 2003$, Assessment of exposure to depleted uranium, Radiation Protect Dos, 105, 157-61. 
19. Stevanović J, Kovačević-Filipović M, Vlaški M, Popović D, Borozan S, Jović S, Božić T, 2005, A Study of Oxidative stress and peripheral blood parameters of cows bred in the area exposed to depleted uranium (DU) ammunition, Acta veterinaria, 55, 4, 269-78.

20. UNEP REPORT, 2001, Depleted Uranium in Kosovo: Post-Conflict Environmental Assessment. United Nation Development Program. Geneva.

21. UNEP REPORT, 2002, Post-Conflict Environmental Assessment Report On Depleted Uranium In Serbia and Montenegro. United Nations Development Program, Geneva.

\title{
ISPITIVANJE OKSIDATIVNOG STRESA I KRVNE SLIKE OVACA ODGAJANIH U REGIJI KOJA JE BILA IZLOŽENA DELOVANJU MUNICIJE SA OSIROMAŠENIM URNIJUMOM (DU)
}

\author{
JOVIĆ S, ALEKSIĆ JELENA, KRSTIĆ ALEKSANDRA, STEVANOVIĆ JELKA, \\ KOVAČEVIĆ-FILIPOVIĆ MILICA, BOROZAN SUNČICA, BOŽIĆ TATJANA \\ i POPOVIĆ DRAGANA
}

\section{SADRŽAJ}

U ovom radu su prikazani rezultati ispitivanja zdravstvenog stanja ovaca odgajanih u regionu koji je bio izložen delovanju municije sa osiromašenim uranijumom (DU) tokom bombardovanja Srbije i Crne Gore 1999. godine, od strane NATO pakta. Uzorci krvi su uzeti tokom 2004. godine od ovaca u regionu Bujanovca, metodom slučajnog izbora. Kompletan pregled krvi obavljen je standardnim laboratorijskim procedurama. Koncentracija malondialdehida u ertirocitima (RBC MDA) i aktivnost eritrocitne superoksid dismutaze (SOD) određene su spektrofotometrijski, dok je funkcionalna aktivnost leukocita ispitana NBT testom redukcije i adhezije.

Rezultati kompletnog pregleda eritrocita su ukazali na postojanje normocitne hipohromne anemije. Ukupan broj leukocita i leukocitna formula su bili u fiziološkim okvirima. Kod životinja izloženih delovanju osiromašenog uranijuma nije bila izmenjena adhezivnost leukocita, ali je pojačana NBT redukcija ukazivala na to da je bio podstaknut njihov oksidativni prasak. Ovaj nalaz, uz značajan porast koncentracije RBC MDA i aktivnosti eritrocitnog antioksidativnog enzima SOD, ukazivali su na postojanje oksidativnog stresa.

Rezultati dobijeni ovim ispitivanjima su upućivali na to da su životinje bile pod oksidativnim stresom, ali nemamo sigurne podatke da je on bio posledica izlaganja dejstvu osiromašenog uranijuma (DU) koji je dospeo u njihovu životnu sredinu tokom vojne akcije u tom regionu. 